Article

\title{
Political Messages in African Music: Assessing Fela Anikulapo-Kuti, Lucky Dube and Alpha Blondy
}

\author{
Uche Onyebadi \\ Department of Journalism, Texas Christian University, Fort Worth, TX 76129, USA; u.onyebadi@tcu.edu
}

Received: 30 September 2018; Accepted: 30 November 2018; Published: 6 December 2018

\begin{abstract}
Political communication inquiry principally investigates institutions such as governments and congress, and processes such as elections and political advertising. This study takes a largely unexplored route: An assessment of political messages embedded in music, with a focus on the artistic works of three male African music icons-Fela Anikulapo-Kuti (Nigeria), Lucky Dube (South Africa), and Alpha Blondy (Côte d'Ivoire). Methodologically, a purposive sample of the lyrics of songs by the musicians was textually analyzed to identify the themes and nuances in their political messaging. Framing was the theoretical underpinning. This study determined that all three musicians were vocal against corruption, citizen marginalization, and a cessation of wars and bloodshed in the continent.
\end{abstract}

Keywords: Political communication; African politics; African music; Fela Anikulapo-Kuti; Alpha Blondy; Lucky Dube; textual analysis

\section{Introduction}

Music permeates significant aspects of African society, culture, and tradition. Adebayo (2017, p. 56) opined that "to the African, music is not just a pastime, it is a ritual" that describes the true essence and humaneness in being of African origin. Cudjoe (1953, p. 280) description of the place of music among the Ewe people in Ghana typifies this African musical heritage. He observed that "music has an important place in the social life of the Ewe people. There is no activity which does not have music appropriate to it: weaver, farmer and fisherman each sings in perfect time to the rhythmic movement of (one's) craft ... there is also the great social music which accompanies religious, festive and ceremonial occasions".

African politics and political activities are also impacted by music. For instance, the history of colonialism and independence in the continent will be incomplete without adequate attention to the music and songs that were used to mobilize people to agitate for political freedom. Grundlingh (2004, p. 486) observed that as far back as the 1930s and 1940s "distinctive forms of township music such as marabi carried with them their own implicit and sometimes explicit political messages" against the apartheid system in South Africa.

In spite of music fundamentally impacting African societies, and the fact that some African musicians and musical groups are known for embedding political messages in their lyrics, only a handful of research such as Labinjo (1982); Grass (1986); Onyebadi and Mbunyuza-Memani (2017); and Louw (2017) have specifically examined how African musicians use their platforms for political messaging. The present study adds to the effort to redress this situation through an examination of political messaging by three male African music icons, Fela Anikulapo-Kuti, Alpha Blondy, and Lucky Dube. The focus on these African music geniuses is partly informed by the fact that they have no doubt left their marks on Africa's political orbit with their scathing commentaries, criticisms, and messaging against the continent's unprogressive governments and corrupt political rulers, the squalid and marginalized lives of huge African populations, and the wars, bloodshed, and other social ills that continue to ravage the continent. Fela and Lucky are now dead, but their popularity has arguably not waned. 
This study was conceptualized to specifically examine how these iconic musicians explored the following themes in the lyrics of some of their songs: Power and corruption; war, bloodshed, and peace; and the concern for citizens. When combined, the three musicians may have recorded over two hundred songs. However, this study was not devoted to analyzing their entire music repertoire or the diversity of issues addressed in their music. Rather, it is about a purposive sample of their songs with political messages enshrined in the themes above. Methodologically, this study relied on a textual analysis of the songs in order to decipher their meanings. For theory, the author chose framing to shed light on how the musicians presented their messages to their audiences.

The overarching research question in this study is about determining how Fela, Lucky, and Alpha presented political messages in their music on the key themes expressed above.

\section{Literature and Theory}

Research on music and political messaging is arguably one of the least addressed areas in political communication inquiry. Dominant issues in this research area include the presidency, congress, voter education and behavior, elections, political advertising, and more recently, the impact of new and social media use on inter-personal and group political discussions (Onyebadi 2017). Yet, musicians across the globe are known to use their platforms and lyrics for political messaging. The late reggae icon, Bob Marley, exemplified this form messaging as he sang about Rastafarianism as a force for change in society, while calling attention to the living conditions of the poor in his country, Jamaica (King and Jensen 1995; Zaid 2001). In 2016, the Sweden-based Nobel Prize committee announced Bob Dylan as the winner of the prize for literature "for having created new poetic expressions within the great American song tradition"-a statement that can be interpreted as a rhetorical recognition of the political messaging in his music. ${ }^{1}$

Africa offers a huge tapestry of political messaging through songs and music. Satti (2017) determined that in the 1960s, Sudanese musician, Mohamed Wardi, used his platform to arouse nationalistic fervor among his compatriots and was quick to support democracy as much as he condemned authoritarian and despotic leadership in his country. Gakahu $(2017$, p. 259) noted that during Kenya's independence struggle against colonial Britain, "most Mau Mau (freedom fighters) songs were a discourse about liberation from colonial injustices such as torture, rape, massacre, castration, forced labor, high taxation, and land displacement". In Zimbabwe, Makwambeni (2017, p. 246) argued that during the regime of former President Robert Mugabe, "Zimdancehall music emerged as an alternative public sphere separate from the state where counter discourse is produced and consumed largely by unemployed urban youths who have been excluded from mainstream communicative spaces". In a rather interesting case of South Africa, Louw (2017, pp. 89-90) pointed out that "Twelve years after Afrikaners lost control of South Africa's political-system, music became a fulcrum for Afrikaners to begin mouthing discontent about their place within the post-apartheid socio-political order. Their 'sullen silence' was broken in 2006 by a song called De la Rey. Because this song's lyrics so resonated with Afrikaner alienation and frustration, it became an instant hit". In Nigeria, Adebayo (2017) observed that the 2015 presidential election in the country was largely peaceful because of the positive role played by Nigerian musicians in urging for peaceful polling and the orderly transfer of power. Allen (2004, p. 1) overview is that while "public contestation" of issues is largely done through the mass media in Western societies, in Africa "people find other ways of voicing who they are ... and what they want. I argue that music constitutes one of the primary media through which such needs are fulfilled".

However, the use of music for political causes in Africa has not always been very positive. Craig and Mkhize (2006) opined that the anti-Tutsi lyrics in Simon Bikindi's songs where he called them "cockroaches," "vicious hyenas", and "blood-thirsty murderers" contributed to the 1994 genocide 
in Rwanda. On the other hand, musicians who sing against siting presidents in the continent oftentimes face official harassment and jail time. Cloonan $(2006$, p. 10) presented the case of Tanzania where "the Sukuma artist Kalikali was jailed in 1965 for singing songs about political corruption, despite his longstanding support for the nationalist cause". South Africa's musician and anti-apartheid campaigner, the late Miriam Makeba, used her voice to effectively deplore the racist Afrikaner government's harassment and killing of black nationalists in her country. In response, the government revoked her South African citizenship and she was forced to live in exile for several years. She only returned to her country in 1991 after Nelson Mandela became South Africa's first black president. The same South African apartheid government in 1975 banned the song Get Up Stand Up, by Bob Marley (originally written with Peter Tosh) because the "authorities were so terrified that his dangerously influential lyrics would incite the people to rise up against them" (Gallardo 2003, p. 203).

\subsection{The Musicians}

A brief insight into the lives and professional activities of the artists used in this study will facilitate a better understanding of their music and political messaging.

Fela Anikulapo-Kuti

Born as Fela Ransome-Kuti, this maverick Nigerian musician made some fundamental changes early in his professional life: (a) Changing his last name to Anikulapo-Kuti, which translates to he who carries death in his pouch, therefore cannot die, and describing "Ransome" as a remnant of British colonialism that was meaningless in his ethnic Yoruba language (Caroll 2013; Olaniyan 2001); (b) abandoning jazz and classical music he learned at the Trinity School of Music in England for Afrobeat music that had a heavy African undertone (Labinjo 1982); (c) renaming his band from Fela and the Koola Lobitos to Fela and the Egypt ' 80 (Dosunmu 2010), to reiterate the African foundation of his art; and (d) jettisoning English language and singing in pidgin English, a localized version of English language, thus identifying with and reaching a vast population of ordinary folk in Nigeria and even beyond in West Africa (Veal 2000).

Fela used his music as a weapon to fight corruption, injustice, and the dysfunctional government in Nigeria and Africa. When he died in 1997, the New York Times described him as a "band leader who combined pulsating Afro-beat rhythms and scathing pidgin English lyrics to goad Nigeria's leaders and denounce their authoritarian regimes ... (and) Africa's most famous musician and his country's foremost political dissident". ${ }^{2}$

\section{Lucky Dube}

Lucky Dube's musical journey began at 18 years old, in his cousin's band, The Love Brothers. While the band was quite popular playing the mbaqanga traditional music of his Zulu ethnic group in South Africa, Lucky knew that he needed to broaden his audience if his message was to have a significant impact. He subsequently transitioned to reggae music, and explained the shift in a British Broadcasting Corporation (BBC) interview shortly before his death: "Mbaqanga is only known in southern Africa and it's mostly sung in Zulu. I wanted my music to be heard-my message-not only in South Africa. Reggae music is found everywhere so reggae was my first vehicle to take this message across to people in the world". ${ }^{3}$

His principal influences in this transition to reggae were two Jamaican reggae icons, Jimmy Cliff and Peter Tosh. Like his idols, Lucky had clarity and resonance in his message. Ofeibea Quist-Arcton, Africa correspondent of the U.S. National Public Radio (NPR), articulated Lucky's legacy after his death: "I think many people are going to remember his message. He took issue ... (with) bad leaders

2 Fela, 58, Dissident Nigerian Musician, Dies. Available online: https://www.nytimes.com/1997/08/04/arts/fela-58dissident-nigerian-musician-dies.html.

3 South Africa's singing peacemaker. (2007). Available online: http://news.bbc.co.uk/2/hi/africa/7054535.stm. 
in Africa, not just in South Africa. He talked to ordinary Africans, telling them that they must overcome the problems of the continent, that they must fight back, but that they must do it with love, respect and, especially, togetherness". ${ }^{4}$ In his obituary, the Economist magazine wrote: "He might have sung Zulu township jive all his life, if he had not felt compelled to give 'a message' to the world for which reggae was his ideal language. The message was peace, unity, love and respect" ${ }^{5}$

In October, 2007, a gang of carjackers shot and killed Lucky Dube as he dropped off two of his kids at his brother's house in Rosettenville, South of downtown Johannesburg, South Africa.

\section{Alpha Blondy}

Côte d'Ivoire's reggae superstar, Seydou Koné, known internationally as Alpha Blondy, has had a most complicated life that saw him being brought up by his grandmother, expelled from college in 1972, "exiled" to Liberia to continue his college education, then migrating to New York in the United States to finish his English language studies. While in New York, he attended a reggae musical concert by the Jamaican reggae musician, Burning Spear, and was drawn to reggae and its style of socio-political messaging.

He explained the greatest influences on his life in a 2013 interview with United Reggae, an online reggae music magazine: "Bob Marley ... the first to come from the ghetto to superstardom. You don't usually see ghetto people on t.v.! And Burning Spear ... and of course my grandmother. She introduced me to African music when she was rearing me. $^{\prime \prime}{ }^{6}$

Peace advocacy and the cessation of wars and conflicts in Africa heavily underscore Alpha's political messaging. In the same United Reggae interview, he articulated his devotion to peace in the continent: "I'm not a politician, but I do try to get them to listen. I try to make them aware of the real human being values. I'm lucky that I can talk to the people. My way of fighting against war for peace is through music. I don't have the absolute truth, but I try to give hope in my songs".

\subsection{Theory: Framing}

Generally, musicians articulate their perceptions of the existential conditions in their community or polity, highlight the importance of those issues and promote and recommend ideas and solutions to their audiences in the lyrics of their songs. This system of communication aligns with the fundamentals of the framing theory. As articulated by Entman (1993, p. 52), framing is the process of "selecting some aspects of a perceived reality and make them more salient in a communicating text in a way as to promote a particular problem definition, causal interpretation, moral evaluation, and/or treatment recommendation". Tankard et al. (1991) equally recognized the elements of "selection, emphasis, exclusion, and elaboration" in framing an issue. Overall, framing deals with highlighting certain aspects of reality to the exclusion of others not considered relevant and salient (Entman 1991, 1993; Gitlin 1980; Nelson et al. 1997).

This study therefore attempts to feature some of the socio-political issues selected and highlighted by Fela, Lucky, and Alpha through their music. Further attempts were made to categorize these issues in line with another theoretical import of framing. As Iyengar and Simon (1993) suggested, framing can be approached in a thematic or episodic manner. Episodic framing deals with issues and events in no strict order or literally as events or issues pop up, while thematic framing organizes or categorizes those issues and events in a given context and subject matter. Thus, while all three musicians addressed multiple issues in their musical career, this study adopted a more thematic approach in examining their songs with political messaging.

4 Africa Update: Lucky Dube Investigation. (2007). Available online: https://www.npr.org/templates/story/story.php? storyId $=15560410$.

5 Lucky Dube. (2007). Available online: https:/ / www.economist.com/node/10015816.

6 Interview: Alpha Blondy Gives Thanks and Praise to the Lord. (2013). Available online: https://unitedreggae.com/articles/ n1291/031213/interview-alpha-blondy-gives-thanks-and-praise-to-the-lord. 
Furthermore, the emphasis in this study is on how the musicians framed and expressed their political messages, not the extent to which they were successful in having their various audiences accept those messages as presented. As Amienyi et al. (2013) and Onyebadi (2017) observed, messages are not always decoded, interpreted, or even accepted as originally conceptualized and framed by their senders.

\subsection{Research Question}

The research question investigated in this paper is as follows: How did Fela Anikulapo-Kuti, Alpha Blondy, and Lucky Dube frame political messages in their music and what themes did they emphasize in their lyrics?

\section{Method}

This study utilized the qualitative textual analysis in its method. Textual analysis involves the examination, interpretation, and making inferential meaning of given texts, the list of which includes films, musical lyrics, advertisements, and even graffiti (Leff 1992; McKee 2003). It is a qualitative instrument that is best suited for studying small volumes of text (Fairclough 2003).

As a meaning-making and interpretative tool, an analyst using it is susceptible to misinterpreting the original intentions of the message composer (McKee 2003), especially in cross-cultural research. Nevertheless, Bogue (2007) reaffirmed its reliability and appropriateness as a method, especially if the researcher pays attention not just to the texts themselves, but also to the nuances that underscore them. Rein and Springer (1986) also made a similar case and recommended that the analyst should adopt a holistic approach towards determining the significance of the text, and not just a few lines or segments in it. In this regard, Onyebadi and Mbunyuza-Memani (2017) further recommended understanding texts in the context of the time and environment in which they were composed, as well as their target audiences.

Combined, the three musicians in this study may have released over two hundred songs in their illustrious careers. However, fourteen songs which represent a purposive sample of their work were used in this analysis (see Appendix A). Such samples are useful and adequate for research because they are based on decisions made by the researcher regarding "what units (songs, in this case) he or she deems appropriate to include in the sample" (Neuendorf 2002, p. 88).

Unlike the other two musicians, Fela wrote most of his lyrics and sang in pidgin English that is popularly spoken in Nigeria and West Africa. Translations were made by this author who is proficient in both English and pidgin English. While Lucky and Alpha used Reggae as their preferred platforms, Fela originated and played Afrobeat, a blend of highlife music that was popular in West Africa, jazz, and Black-American soul music (Labinjo 1982; Lena and Peterson 2011).

This study also adopted a thematic approach (Iyengar and Simon 1993) in the examination of the songs by all three musicians, categorizing them into three broad subject areas:

(a) Power and Corruption: Songs about the abuse of power and how people in authority corruptly enrich themselves at the expense of the broader populations. Fela Anikulapo-Kuti's songs fall in here.

(b) War, Bloodshed, and Peace: Songs in this theme are about the cessation of wars and bloodshed in Africa, and appeal for peace in the continent. Alpha Blondy's songs are represented in this theme.

(c) Concern for Citizens: These are songs about ordinary citizens, and how the hypocrisy and selfishness of the ruling elite impact the rest of the community. Songs analyzed in this theme belong to Lucky Dube. 


\section{Analysis and Discussion}

\subsection{Power and Corruption (Fela)}

Fela Anikulapo-Kuti was obsessed with fighting corruption and lambasting government officials who abused their power. Olaniyan (2001, pp. 77-78) observed that what bothered Fela were "tyrannical leadership, political instability, flagrant disregard for rules, and entrenched nepotism as currency of official transactions ... His exasperations seem to be not so much with the crises as with their seeming permanence, their normalization."

In the song, Colonial Mentality (1977), Fela set the stage for his vitriolic criticism of African leaders by describing them as people who were still entrapped in colonial mentality. He sarcastically sang:
He be say you be colonial man
You look like a colonial man
You don be slave man before
You were once a slave
Them don release you now
They have now freed you
But you never release yourself
But you have not freed yourself
I say you fit never release yourself
I say you can't even free yourself of
Colo-mentality
Colonial mentality

This sarcastic description had been elaborated in the song, Mr. Grammarticalogylisationalism Is the Boss (1975), where he derided the leaders as people whose language and grammatical choices distanced them from the ordinary folk they governed. Fela sang:

They, na de man

(Which man?)

Wey talk oyinbo well well to rule

our land o

(That man!)

Oh yes

\section{[Chorus]}

Him talk oyinbo pass English man!

Him talk oyinbo pass America man

Him talk oyinbo pass French man

Me I say him talk oyinbo pass German man

He then continued:

First thing for early morning

Na newspaper dem give us read

The oyinbo wey dey inside

Petty trader no fit to know

The oyinbo wey dey inside

Market woman no fit to read

The oyinbo wey dey inside

$\mathrm{Na}$ riddle for laborer man

Inside the paper

Lambastical dey

Inside the paper
He is the man

Which man

Who speaks fluent English to rule us

That man

Oh yes

He speaks English more than an English man

He speaks English more than an American man

He speaks French more than a French man

I say he speaks German more than a Germany man

First thing early in the morning

They give us a newspaper to read

The English language in the newspaper?

A petty trader does not understand

The English language in the newspaper?

Ordinary woman in the market cannot read

The English language in the newspaper?

Is a riddle to a lowly-paid laborer

In that newspaper

You'll find "Lambastical"

In that newspaper 
Ipso facto dey, that one na Latin

Inside the paper

Jargonism dey

Inside the paper

Youth delinquency dey

Who be delinquent?

Na dem be delinquent

Who be delinquent?

The oyinbo talker delinquent

Who be delinquent?

It no be me o

They, na de man

(Which man?)

Wey talk oyinbo well well to rule

Our land o...
You'll find ipso facto, which is Latin

In that newspaper

You'll find "Jargonism"

In that newspaper

You'll find youth delinquency

Who is delinquent?

They are the delinquents

Who is delinquent?

The person who speaks in English

Who is delinquent?

It isn't me

It is the man

Which man?

Who speaks fluent English to rule us ...

In the next song, V.I.P. (1979), Fela twisted what the acronym stood for (Very Important Person) to Vagabonds In Power to show how detestable people in powerful positions and authority appear to him, and how they corruptly enrich themselves and care very little for their constituents. The song describes various forms of power in society, from the power a man who uses his make-shift wheel-barrow to carry goods for people in the market for a fee, to that of the head of state, and asks what the latter does with his power. His response:

Him take am

Steal money

Ha ha, why?

I don't know! I don't know

You don't know anything at all

You just my brother, ha ha

Try this one:

Him no know hungry people Him no know jobless people

Him no know homeless people

Him no know suffering people

Him go dey ride best car

Him go dey chop best food

Him go dey live best house

Him go dey waka for road

You go dey commot for road

for am

Him go dey steal money

$\mathrm{Na}$ "Vagabond in Power"!
He (head of state) uses it (power)

To steal money

Ha ha, why?

I don't know! I don't know (someone replied)

You don't know anything at all

You are just my (ignorant) brother, ha ha

Try this one:

He doesn't know hungry people (or, that people are hungry)

He doesn't know that people are jobless

He doesn't know that people are homeless

He doesn't know that people are suffering

He will ride the best car

He will eat the best food

He will live in the best house

If he walks along the road

You will get off the road for him to pass

He will steal (people's) money

He is a Vagabond in Power...

Fela was not only infuriated by the propensity for Vagabonds in Power to embezzle funds but also the fact that they steal with a sense of authority and impunity and go unpunished. In the song, Authority Stealing (1980), Fela ironically laments the fate of the local small-time thief who earns excessive punishment while people in power who steal at a much larger scale go scot-free. He begins with the imagery of people or mob chasing the small-time thief in an unnamed African country, by singing their typical catcalls in such a robbery incident: 

Catch am, catch am! Thief, thief, thief!
Catch the thief
Catch am, catch am! Rogue, rogue, rogue!
Catch the rogue
Catch am, catch am! Robber, robber!

[And when the thief is caught by the mob ...... ]

Them go beat am well-well

Them go lynch am well-well

Police go come well-well

Them go carry am go court

Them go put am for jail

Them fit put am six months

Them go put am for one year

Them fit put am two years

Them go put am for five years

Them fit put am seven years

Them go put am for ten years

If not them go shoot am well

Them go shoot am for armed robbery ...
They will beat him thoroughly

They will lynch him completely

Then, the Police will arrive

They will arraign him in court

They will jail him

They might jail him for six months

They might jail him for one year

They might jail him for two years

They might jail him for five years

They might jail him for seven years

They might jail him for ten years

If not, they will shoot him completely

They will shoot him for armed robbery ...

At this point, Fela turns attention to the fate of people in authority who steal stupendous amounts of public money but go unpunished. Ironically, they only use their pens to accomplish what armed robbers with guns could not achieve.

I say turn your face small

To the right wing

Oga patapata dey for there

Authority people dey for there

Authority people them go dey steal

Public contribute plenty money

$\mathrm{Na}$ authority people dey steal

Authority man no dey pickpocket

Na petty cash him go dey pick

Armed robber him need gun

Authority man him need pen

Authority man in charge of money

Him no need gun, him need pen

Pen got power gun no get

If gun steal eighty thousand naira

Pen go steal two billion naira...
I say, turn your face to the other side

To your right

The boss is there

People in Authority are there ... ...

Authority people will steal

So much money contributed by the public

That's what Authority people steal

Authority man is not a pick-pocket

$\mathrm{He}^{\prime} \mathrm{ll}$ pick petty cash (pun, not pocket)

Armed robber needs a gun

Authority man needs a pen

Authority man is in charge of money

So, he doesn't need a gun; he needs a pen

Pen has power; a gun doesn't

If gun steals eighty thousand Naira (about \$230)

Pen will steal two billion naira (about $\$ 5.8$ million)

Another irony, Fela points out, is that no one will shout "thief" or "robber" about the massive theft by people in authority, possibly because those who are supposed to prosecute them are their cronies who also got their share of the loot. Thereafter, the authority people and their allies will ingeniously invent some words to camouflage their pillage in order to make the incident look much more innocuous and different from the theft it is. Fela went on: 
Hear the words them dey

take deceive the people:
Hear the words that will be used to deceive people:

Misappropriation

Maladministration

Nepotism

Mitigation

Make I remember another one wey them dey use

(Let me remember other words they use)

Defraudment

Forgerylization

Embezzlement

Vilification

Mismanagement

Public inquiry

Finally, Fela pronounced his indictment:

\author{
Authority stealing pass armed robbery \\ We Africans we must do something \\ about this nonsense \\ We say we must do something \\ about this nonsense \\ I repeat, we Africans we must do \\ something about this nonsense \\ Because now authority stealing \\ pass armed robbery ...
}

\author{
Authority stealing is worse than armed robbery \\ We Africans must do something \\ about this nonsense \\ We say we must do something \\ about this nonsense \\ I repeat, we Africans must do \\ something about this nonsense \\ Because authority stealing is \\ worse than armed robbery ...
}

In another song, Confusion Break Bones (1990), the singer is exasperated that corruption and bad governance had become seriously endemic, if not normalized. According to him:
If I sing-ee say, Inf-i-lati-on
If I sing about inflation
If I sing-ee say, mismanagement
If I sing about mismanagement
If I sing-ee say, corrup-u-tion
If I sing about corruption
If I sing-ee say, stealing by government
If I sing about stealing by government
Na old old old news be dat-ee-oh
Those are old news
Di problems still dey ba'gba ra 'gba ...
The problems are still there, so strong ...
Dey thing weh dey worry me
What worries me
How dis robbery come get-ee
Is how this robbery got a big head ...
big-ee head...

\section{HEAD-O ROBBO-ERY Head}
Where oga pata-pata
go-go steal (everything)
He go take position, steal all free
Free stealing, na him policy
Head robbery (pun)
Where the big boss will steal everything
He'll use his position to steal freely
Free stealing is his policy ...

[And, Fela winds it up with a rhetorical question]

Which president we get-ee never steal?

Which (Nigerian) president has not stolen (people's money)?

Fela did not disguise his disenchantment with Nigeria's, and Africa's, leaders. He clearly branded them as people who were incapable of shedding their colonial mentality but were adroit at hiding 
their bad governance with complex lexical jargons that obscured shared meaning with the rest of the population. More importantly, he presented them as unconscionable looters of public funds. The lyrics of Authority Stealing appear to epitomize his disgust. He identified official corruption and the embezzlement of public money as society's leukemia and urged Africans to rise up and "do something about this nonsense".

Authority Stealing was released in 1980. However, the specter of stealing with authority never abated, years after Fela's death in 1997. The extent of the pilfering of public funds he identified and consistently campaigned against was extensively discussed in 2011 at the fourth joint meeting of the African Union and the United Nations Economic Commission for Africa (ECA). The meeting mandated the ECA to investigate what it called the "Illicit Financial Flows (IFF) from Africa" the core of which is the embezzlement of public funds. The committee's report stated that "currently, Africa is estimated to be losing more than $\$ 50$ billion annually in IFFs". ${ }^{7}$

\subsection{War, Bloodshed and Peace (Alpha Blondy)}

The decimating flames of war and conflict in Africa that Alpha Blondy sang about a few decades ago remain of contemporary relevance and importance. The interminable wars in the Democratic Republic of Congo and South Sudan attest to this. Added to the carnage are the grisly activities of non-state actors such as Boko Haram in Nigeria, Al Shaba in Somalia and the Al-Qaeda in the Islamic Maghreb (AQIM) in Mali.

Alpha Blondy's summation of the cataclysmic consequences of wars and conflicts in Africa is embedded in the song, Bloodshed in Africa (1986). The song commences with a lamentation, then a resolve to oppose bloodshed associated with Babylon:

Bloodshed in Africa, bloodshed in Africa

What a shame, what a shame

It's a bloody shame, oh yeah

It's a mighty shame, oh Lord

See Babylonians are coming around

And are messing around with my people's mind

I can't stand it

No, I won't bear it

Alpha Blondy is a reggae musician. In this music genre, Babylon has a great deal of sinister symbolism. Early Rastafarians lived in Trenchtown, a squalid part of Kingston, Jamaica's capital city. Trenchtown was the Rastafarians' Babylon which, according to Davidson (2008), represented evil and inhumanity. Rastafarianism is thus a struggle for redemption from poverty, disease, destruction, bloodshed, and insecurity. In spite of the destructiveness and evil of the African Babylon, Alpha Blondy is optimistic that the situation will eventually peter away. He prophesized that Africa's wars and conflicts were bound to end at some point. He sang about it this way:

You see, Babylon you bound to fall

You bound to fall, you bound to burn down

Babylon you bound to fall

You bound to fall, you bound to melt to the ground

Some of the on-going wars when he released Bloodshed in Africa were in Angola, Chad, and Ethiopia. However, perhaps nowhere in his songs did Alpha Blondy specifically and almost

7 Illicit Financial Flows. (n.d.). Available online: https://www.uneca.org/sites/default/files/PublicationFiles/iff_main_ report_26feb_en.pdf. 
vociferously call for peace and the cessation of wars as in the case of Liberia where he spent a part of his childhood, and a country which was involved in very tumultuous and destructive wars for seven years. In Peace in Liberia (1992), he made a passionate plea for peace, noting that wars can only damage and destroy the country since both victors and the vanquished suffer the pains of wars:

We want peace in Liberia, peace in Monrovia

We want peace in Liberia, peace in Monrovia

‘Cause Babylon shall not rise again ...

'Cause every day they talking about

The Liberian Civil War

And everywhere over Jah land

Muddy rivers of blood oh Lord!

No matter who wins, Liberia is crying

No matter who lose, Liberia still crying

No matter who's right, they've got to stop the fight

No matter who's wrong, the devil still stronger

So we want peace in Liberia, peace in Monrovia

We want peace in Liberia, peace in Monrovia

And Babylon shall not rise again ...

Sudan (prior to the country splitting into two and South Sudan becoming independent on 9 July 2011) was another hotbed of bloodshed and wars identified in Alpha Blondy's music. He was quite forthright that the war in the Sudan was precipitated by religious bigotry (Islam vs Christianity) and racism (Northern Sudanese of Arab descent vs south Sudanese of indigenous ethnicities). He forcefully expressed his bewilderment that in spite of the bloodshed that was taking place in the Sudan, the Organization of African Union (OAU), now known as African Union (AU) literally watched by the sidelines as the country got engulfed in a towering inferno of human and material destruction. In the song, Take no Prisoner (1999), the musician vividly painted a gruesome picture of what he thought was going on in the country: Racism, pogrom, and religious intolerance. He called the domination of Sudanese in the southern part of the country by their northern compatriots in power as modern-day slavery and cannibalism, and sang as follows:

Down in Sudan

Muslims are selling Christians as slave...

I don't understand

How Africa got into this craze ...

O.A.U. don't care

Freedom fighters beware

It's a cannibalistic strategy

A cannibalistic strategy

The reference to "cannibalistic strategy" could symbolize some form of pogrom or genocide which, like cannibalism, is designed to exterminate a people because the conquering authorities, as he sang, appeared to have a policy of "we take no prisoners and we eating the wounded." This is a reference to genocide against the Southern Sudanese.

The devastating impact of the official policy of apartheid or racial segregation in South Africa also formed the theme of one of his songs, Apartheid is Nazism, released in 1985. The official segregationist policy of the ruling white, Nationalist Party government in South Africa, practically meant the planned killing, maiming, and subjugation of all non-white population in the country, especially black Africans, 
to terrorism of the mind and body. Noting in the song that the government in South Africa had no "right to shoot the children," Alpha Blondy called on the United States, as a global super power, to do something to halt the carnage in South Africa. He sang as follows:

America, America, America

Break the neck of this apartheid

America, America, America

Break the neck of this apartheid

This apartheid system is nazism, nazism, nazi

This apartheid system is nazism, nazi, them a nazi

This apartheid system is nazism, nazi, them a nazi

It is somewhat curious that Alpha Blondy appears to believe in some form of divine intervention as a solution to wars and bloodshed in the African continent. In Peace in Liberia (1992), he offered the following supplications, apparently outsourcing solutions to wars in Liberia to the heavens:

So we want peace in Liberia, peace in Monrovia

We want peace in Liberia, peace in Monrovia

And Babylon shall not rise again

Babylon shall not rise again

Babylon shall not stand again

Babylon shall not stand again

Calling on Jesus Christ to save I and I

We calling Jesus Christ to save I and I

We calling on Allah to save I and I

We calling Adonai to save I and I

However, it was in his song, Come Back Jesus (1985), that Alpha Blondy made the most elaborate supplication for divine presence to end the wars and conflicts that afflicted Africa; wars which had defied human attempts at peacefully resolving them. He set out in the song to question the rationale for the wars in the continent.

Why they're fighting war

And I wonder why they're fighting war

Said, I wonder why now

Why they're fighting war

Without proffering an answer, the musician sought refuge in the power of the Christian Jesus to end the conflicts and save the continent from further bloodshed. He pleaded:

Oh, come back Jesus

Come back light

Come back Jesus, my Lord

Come back love

Then come back Jesus

Come back light

Come back Jesus, Jesus, my Lord

Come back love

Peace and love 
Peace and love now

Jesus, Jesus

Bring peace and love

Oh, my Jesus

My sweet Jesus

My heart Jesus

My soul aches for you

Teardrops coming through

Love, love, love, love

We need love

Sweet Lord, now

We need you ......

Alpha Blondy's Come Back Jesus was released in 1985. However, the wars he sang about continue to rage in the continent. According to Africacheck.org, which monitors wars and conflicts in Africa, 8300 people were killed in the continent in January and February of 2015. Five countries in sub-Saharan Africa (Nigeria, Cameroon, Sudan, Somalia and Niger) accounted for about 90 percent of those deaths. ${ }^{8}$

\subsection{Concern for Citizens (Lucky Dube)}

It is the common folk that bear the hardship brought about by ineffective and corrupt governments. This is the undertone in Lucky Dube's songs in this study. After decades of independence by several African countries, the prospects for ameliorating the plight of ordinary citizens remain deem. Rather, the rich and powerful continue to consolidate their wealth and affluence. For instance, a Nigerian senator, Shehu Sani from Kaduna state, in March 2018 disclosed that he and each of his colleagues were paid about $\$ 40,000$ per month in salaries and allowances in a country where a majority of the population survived on about $\$ 2$ per day. ${ }^{9}$

According a World Bank report on sub-Saharan Africa, a 3.1 percent economic growth for the continent was expected in 2018, with a projected average increase to 3.6 percent in the 2019-2020 period. ${ }^{10}$ Nonetheless, the continent's economic situation remains grim. The same report concluded the following:

Public debt levels are rising, which might jeopardize debt sustainability in some countries; the availability of good jobs has not kept pace with the number of entrants in the labor force; and poverty is widespread. While the region's per capita gross domestic product (GDP) growth will turn positive in 2018, it will remain insufficient to reduce poverty significantly. Total poverty headcount at the international poverty line ( $\$ 1.90$ per day) is projected to decline only marginally.

The widespread poverty among the marginalized people he saw around him appeared to have puzzled Lucky Dube and left him wondering why the leadership in his society did little to positively address the situation. In Crime and Corruption (1999), he lamented the politicians' apparent indifference to the parlous conditions of life among their fellow citizens and expressed his disgust in rhetorical questions:

8 FACTSHEET: Conflict-related deaths in sub-Saharan Africa. (2015). Available online: https://africacheck.org/factsheets/ conflict-related-deaths-in-sub-saharan-africa/.

9 Uproar Over Parliamentary Salaries in Nigeria, Again. (2018). Available online: https://www.cfr.org/blog/uproar-overparliamentary-salaries-nigeria-again.

10 The World Bank in Africa. (n.d.). Retrieved from http:/ /www.worldbank.org/en/region/afr/overview. 
Is it the bodyguards around you

Is it the high walls where you live

Or is it the men with the guns around you

Twenty four hours a day

That make you ignore the crying of the people

Farmers get killed everyday

And you say it is not that bad

Policemen get killed everyday

And you say it is not that bad

Maybe if you see it through the eyes

Of the victims

You will join us and fight this

Chorus:

Crime and corruption

Do you ever worry

About your house being broken into

Do you ever worry

About your car being taken away from you

In broad daylight

Down highway 54

Do you ever worry

About your wife becoming

The woman in black

Do you ever worry

About leaving home and

Coming back in a coffin

With a bullet through your head

So join us and fight this

Chorus:

Crime and corruption

In yet another song, Political Games (2006), Lucky Dube condemned how politicians whip up patriotic fervors among the people for their selfish ends. He also criticized their nonchalance about the dire human condition of their hapless compatriots, as well as their penchant to peddle falsehood and make unfulfilled promises to hoodwink the masses. His tirade against the leaders was as direct as it was vitriolic:

How do you feel when you lie?

Straight faced while people cry

How do you feel when you promise something

That you know you'll never do

Giving false hope to the people

Giving false hope to the underprivileged

Do you really sleep at night?

When you know you're living a lie

To you it is just a job

To the people it hurts to the bone 
Chorus:

Ooh political games that they play [x4]

What do you say to the orphans?

Of the women and men you sent to war

What do you say to the widows?

Of the men you sent to war

Telling them it is good for the country

When you know it's good for your ego

What a shame.

Do you really sleep at night?

When you know you're living a lie

You talking tough, you talking sincerely

Giving false hope to the infected

Giving false hope to the affected.

To you it is just a job

To the people it hurts to the bone...

In The Hand that Giveth (1989), Lucky Dube explored the biblical injunction about caring for the poor to criticize the rich and powerful for their unbridled hypocrisy in taking money from poor people instead of giving it to them. He may have resorted to using the biblical imperative in the hope that the leaders, who publicly professed embracing Christianity, would practice what the bible said about the virtues of charity. Yet again, he adopted his rhetorical questioning style to amplify his message.

What type of rich man are you

Who doesn't care about the poor people?

What type of rich man are you

Who doesn't care about the helpless people? ...

There you read it in the Bible

But don't understand what it says

It says blessed is the hand that giveth

Than the one that taketh...

Does it make you feel happy

When you see another man starving?

Does it make you feel happy

When you see another man with no food?

Does it make you feel great, maybe?

To see another man, without a thing

You read about it in the Bible

But didn't understand it

Blessed is the hand that giveth

Than the one that taketh ...

In a way, Lucky Dube called for a revolution by the masses against their oppressors in Well Fed Slave/Hungry Free Man (1997). In the song, he suggested that the suffering masses had a choice: Continue to live under the yoke of the squalor that defined their existence or do something to redress their misfortune. In other words, remain a slave or be a free person.

He introduced the song by urging the poor and oppressed to do some self-examination: 
Look in the eyes of the

Homeless man

Tell me what you see

In the eyes of a jobless man

Tell me what you see

What about the eyes

Of a prisoner

What do you see

Now you've seen it all

It is time to make up your mind

Don't try to hide it

'Cause I can see it all

In your face yeah

It the same questions

That I ask myself every time

To be or not to be

From this self-examination he posed a series of poignant questions to the poor and downtrodden:

Do you wanna be

A well fed slave or a hungry free man

What is the point in being free

When you can't get no job

What is the point in being free

When you can't get food

What is the point in going out to work

When others can get for free

What is the point in being free

When you don't have no home

Now you've heard it all

It is time to make up

Your own mind

To be or not to be

Oh ho ho ho...

Do you wanna be

A well fed slave or a hungry free man

By asking his impoverished compatriots to make a choice between pretending to be well fed slaves under unprogressive leadership and breaking free from their bondage and go hungry as free people, Lucky Dube was invariably calling for some form of mass revolution against the ruling elite and status quo.

It was a twist of fate and irony that the poverty and insecurity Lucky Dube highlighted in his songs provided the scenario that cut short his life when he died in a carjacking incident in 2007.

\section{Conclusions}

Fela Anikulapo-Kuti, Alpha Blondy, and Lucky Dube used their music to articulate, frame, highlight, and disseminate political messages on the three main themes in this study: The flagrant abuse of power and corruption; interminable wars and conflicts that threaten peace in the continent; 
and the poor and insecure lives of marginalized citizens whose governments are run by leaders who appear more concerned with personal aggrandizement than with improving the quality of life of their citizens through good governance.

The musicians were forthright in framing their political messaging. They adopted a thematic approach in getting their messages across, that is, all songs played at various points in their careers drove the critical message of interest to each of them. Fela, for instance, was focused on framing and presenting Nigerian and African leaders as utterly corrupt and abusers of political power and authority. He characterized them as unprincipled leaders who were out of touch with the citizenry in Colonial Mentality, Vagabonds in Power and Mr. Grammarticalogylisationalism Is the Boss. In Authority Stealing, the same leaders were framed as brazen and unconscionable looters of their countries' wealth and resources.

In Bloodshed in Africa, Take no Prisoner, Apartheid is Nazism, Peace in Liberia and Come Back Jesus, Alpha Blondy examined the cataclysmic consequences of wars and conflicts in Africa and explored the prospects for peace, even if it meant supplications to the Christian Jesus to intervene and halt the destruction that was ravaging the continent. All songs were framed with the same purpose: End wars and welcome peace in the continent.

Lucky Dube framed his songs around his concern for marginalized citizens, but adopted an approach that rhetorically asked politicians and rulers if they were comfortable with seeing and witnessing the results of their ineptitude, indifference, and lack of care for the people they were elected to serve. Crime and Corruption, Political Games, The Hands that Giveth, Well fed, and Slave/Hungry Free Men all echo the same theme.

As a result of their political messaging, all three musicians examined in this study were branded as renegades and anti-establishment persona in their various countries. This might be one level of evidence that their political messaging had some impact in society, and that music is an effective tool in the African political arena. The security agencies in Nigeria, Côte d'Ivoire, and South Africa closely monitored the activities of Fela, Alpha, and Lucky, respectively. Perhaps, the Nigerian security agencies' harassment and attempted intimidation of Fela were the most extreme examples of perceived threat the authorities in the three countries felt about the musicians and their political messaging. On 18 February 1977, an estimated number of 1000 armed soldiers swooped on Fela's compound called Kalakuta Republic in the capital city Lagos, and burned it down. The military government's inquiry that was set up to investigate the incident attributed the mayhem to the handwork of some "Unknown Soldiers," words which Fela later used as the title of one of his most popular anti-establishment songs.

Fela Anikulapo-Kuti, Alpha Blondy, and Lucky Dube are not the only African musicians with explicit political messaging in their songs. The task for future studies in this genre is to explore and examine the musical repertoire of other African musicians, especially the more contemporary artists, to determine how they use their platform to disseminate political messages to their followers and larger audiences.

Funding: This research received no external funding.

Conflicts of Interest: The author declares no conflict of interest.

\section{Appendix A. Songs Used in This Study}

\section{Alpha Blondy}

Apartheid Is Nazism (1985)

Bloodshed in Africa (1986)

Come Back Jesus (1985)

Peace In Liberia (1992)

Take No Prisoner (1999)

Source: https://lyrics.az/alpha-blondy/allsongs.html 


\section{Fela Anikulapo-Kuti}

Authority Stealing (1980)

Colonial Mentality (1977)

Confusion Break Bones (1990)

Mr. Grammarticalogylisationalism Is the Boss (1975)

Vagabonds in Power (1979)

Source: http: / / www.songlyrics.com/fela-kuti-lyrics /

\section{Lucky Dube}

Crime \& Corruption (1999)

Political Games (2006)

The Hand That Giveth (1989)

Well Fed Slave/Hungry Free man (1997)

Source: https:/ /lyrics.az/lucky-dube/allsongs.html

\section{References}

Adebayo, Joseph Olusegun. 2017. 'Vote not Fight': Examining music's role in fostering non-violent elections in Nigeria. African Journal on Conflict Resolution 17: 55-77.

Allen, Lara. 2004. Music and politics in Africa. Social Dynamics 30: 1-19. [CrossRef]

Amienyi, Osauohien P., Uche Onyebadi, and Mohammed K. Tahat. 2013. Framing conflicts in Africa: A comparative analysis of United States and the Uunited Kingdom news outlets. International Communication Research Journal 48: 52-70.

Bogue, Ronald. 2007. Deleuze's Way: Essays in Transverse Ethics and Aesthetics. Hampshire: Ashgate Publishing Ltd. Caroll, James Gregory. 2013. Composing the African Atlantic Sun Ra, Fela Anikulapo-Kuti, and the Poetics of African Diasporic Composition. Ph.D. dissertation, University of Massachusetts, Amherst, MA, USA.

Cloonan, Martin. 2006. Popular music censorship in Africa: An overview. In Popular Music Censorship in Africa. Edited by Michael Drewett and Martin Cloonan. Ashgate Popular and Folk Music Series. London: Ashgate Publishing, pp. 3-21. ISBN 9780754652915.

Craig, Dylan, and Nomalanga Mkhize. 2006. Vocal Killers, silent killers: Popular media, genocide, and the call for benevolent censorship in Rwanda. In Poplar Music Censorship in Africa. Edited by Michael Drewett and Martin Cloonan. Hampshire: Ashgate Publishing Limited, pp. 39-52.

Cudjoe, Seth D. 1953. The techniques of Ewe drumming and the social importance of music in Africa. Phylon 14: 280-91. [CrossRef]

Davidson, Steed V. 2008. Leave Babylon: The trope of Babylon in Rastafarian discourse. Black Theology: An International Journal 6: 46-60. [CrossRef]

Dosunmu, Oyebade A. 2010. Afrobeat, Fela and beyond: Scenes, Style and Ideology. Ph.D. dissertation, University of Pittsburgh, Pittsburgh, PA, USA.

Entman, Robert M. 1991. Framing US coverage of international news: Contrasts in narratives of the KAL and Iran Air incidents. Journal of Communication 41: 6-27. [CrossRef]

Entman, Robert M. 1993. Framing: Toward clarification of a fractured paradigm. Journal of Communication 43: 51-58. [CrossRef]

Fairclough, Norman. 2003. Analyzing Discourse: Textual Analysis for Social Research. New York: Routledge.

Gakahu, Nancy. 2017. Lyrics of Protest: Music and political communication in Kenya. In Music as a Platform for Political Communication. Edited by Uche Onyebadi. Hershey: IGI Global, pp. 257-73.

Gallardo, Angelica. 2003. Get up, Stand up. Peace Review 15: 201-8. [CrossRef]

Gitlin, Todd. 1980. The Whole World Is Watching: Mass Media in the Making $\mathcal{E}$ Unmaking of the New Left. Berkeley: University of California Press.

Grass, Randall F. 1986. Fela Anikulapo-Kuti: The Art of an Afrobeat Rebel. The Drama Review 30: 131-48. [CrossRef]

Grundlingh, Albert. 2004. "Rocking the Boat" in South Africa? Voëlvry Music and Afrikaans Anti-Apartheid Social Protest in the 1980s. The International Journal of African Historical Studies 37: 483-514. [CrossRef] 
Iyengar, Shanto, and Adam Simon. 1993. News coverage of the Gulf Crisis and public opinion: A study of agenda-setting, priming, and framing. Communication Research 20: 365-83. [CrossRef]

King, Stephen, and Richard Jensen. 1995. Bob Marley's "Redemption Song": The rhetoric of reggae and Rastafari. The Journal of Popular Culture 39: 17-36. [CrossRef]

Labinjo, Justin. 1982. Fela Anikulapo-Kuti: Protest music and social processes in Nigeria. Journal of Black Studies 13: 119-35. [CrossRef]

Leff, Michael. 1992. Things made by words: Reflections on textual criticism. The Quarterly Journal of Speech 78: 223-31. [CrossRef]

Lena, Jennifer C., and Richard A. Peterson. 2011. Politically Purposed Music Genres. American Behavioral Scientist 55: 574-88. [CrossRef]

Louw, Eric P. 2017. Afrikaner music and identity politics in post-apartheid South Africa: Bok van Blerk and the De la Rey phenomenon. In Music as a Platform for Political Communication. Edited by Uche Onyebadi. Hershey: IGI Global, pp. 89-108.

Makwambeni, Blessing. 2017. Zimbabwe dancehall music as a site of resistance. In Music as a Platform for Political Communication. Edited by Uche Onyebadi. Hershey: IGI Global, pp. 238-56.

McKee, Alan. 2003. Textual Analysis: A Beginner's Guide. London: Sage.

Nelson, Thomas. E., Rosalee Clawson A, and Zoe M. Oxley. 1997. Media framing of a civil liberties conflict and its effect on tolerance. American Political Science Review 91: 567-83. [CrossRef]

Neuendorf, Kimberly. A. 2002. The Content Analysis Guidebook. Thousand Oaks: Sage Publications.

Olaniyan, Tejumola. 2001. The Cosmopolitan Nativist: Fela Anikulapo-Kuti and the Antinomies of Postcolonial Modernity. Research in African Literatures 32: 76-89. [CrossRef]

Onyebadi, Uche. 2017. Bob Marley: Communicating Africa's political liberation and unity through reggae music. International Communication Research Journal 52: 56-78.

Onyebadi, Uche, and Lindani Mbunyuza-Memani. 2017. Women and South Africa's Anti-Apartheid Struggle: Evaluating the Political Messages in the Music of Miriam Makeba. In Music as a Platform for Political Communication. Edited by Uche Onyebadi. Hershey: IGI Global, pp. 31-51.

Rein, Irving J., and Craig M. Springer. 1986. Critical response and reply: Where's the music? The problems of lyric analysis. Critical Studies in Mass Communication 3: 252-56. [CrossRef]

Satti, Mohamed A. 2017. Musical Messages: Framing Political Content in Sudanese popular songs. In Music as a Platform for Political Communication. Edited by Uche Onyebadi. Hershey: IGI Global, pp. 187-203.

Tankard, James, Laura Hendrickson, Jackie Silberman, Kris Bliss, and Salma Ghanem. 1991. Media frames: Approaches to conceptualization and measurement. Paper presented at the Association for Education in Journalism and Mass Communication, Boston, MA, USA, August 7-10.

Veal, Michael E. 2000. Fela: The Life and Times of an African Musical Icon. Philadelphia: Temple University Press.

Zaid, Bouziane. 2001. Bakhtin's Dialogic Model and Popular Music: Bob Marley and the Wailers as a case study. In Culture and Mass Communication in the Caribbean: Domination, Dialogue, Dispersion. Edited by Humphrey A. Regis. Gainesville: University Press of Florida, pp. 139-48.

(c) 2018 by the author. Licensee MDPI, Basel, Switzerland. This article is an open access article distributed under the terms and conditions of the Creative Commons Attribution (CC BY) license (http:/ / creativecommons.org/licenses/by/4.0/). 